Krylyuk V. O., Grodetskyi V. K., Fedoseyeva O. V., Garian S. V. Dynamics of antioxidant-prooxidant balance in abdominal injury with underlying hypovolemic shock and reperfusion syndrom of the limbs in experiment. Journal of Education, Health and Sport. 2020;10(1):113-127. eISSN 2391-8306. DOI http://dx.doi.org/10.12775/JEHS.2020.10.01.013

https://apcz.umk.pl/czasopisma/index.php/JEHS/article/view/JEHS.2020.10.01.013

http://dx.doi.org/10.5281/zenodo.3630627

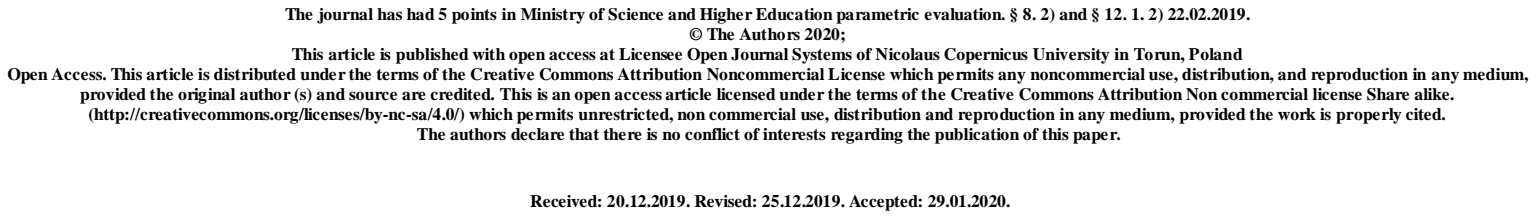

UDC 617.553-001.36-005.1-06:617.58:577.12

\title{
DYNAMICS OF ANTIOXIDANT-PROOXIDANT BALANCE IN ABDOMINAL INJURY WITH UNDERLYING HYPOVOLEMIC SHOCK AND REPERFUSION SYNDROM OF THE LIMBS IN EXPERIMENT
}

\author{
V. O. Krylyuk ${ }^{1}$, V. K. Grodetskyi ${ }^{2}$, O. V. Fedoseyeva ${ }^{3}$, S. V. Garian ${ }^{4}$ \\ ${ }^{1}$ GO «Ukrainian Scientific and Practical Center of Emergency and Disaster Medicine \\ Ministry of Health of Ukraine» \\ ${ }^{2}$ Higher State Educational Establishment of Ukraine «Bukovinian State Medical \\ University» \\ ${ }^{3}$ Cherkasy Medical Academy, \\ ${ }^{4}$ I. Ya. Gorbachevskiy Ternopil State Medical University
}

\begin{abstract}
The article describes the results of the experimental study in which the effect of ischemic-reperfusion limb syndrome on changes in the internal organs was studied. Changes in the values of Malone dialdehalide, superoxide dismutase and catalase in the tissues of the kidneys, liver, lungs and muscles of the extremities were studied. These studies confirmed the hypothesis and proved the presence of signs of systemic changes as a result of applying a hemostatic tourniquet, the presence of potentiating effects of reperfusion syndrome with a combined injury of the abdominal cavity against the ground of hypovolemic shock.
\end{abstract}

Key words: trauma; abdominal cavity; bleeding; experiment; reperfusion. 


\section{Introduction}

In the same way as before injury is a leading cause of death, especially in individuals of able-to-work age, and it produces a considerable social and economic effect on public life $[1,2,3]$. According to "The World Report On Road Safety" over 1,2 million of people are killed on the roads annually, and more than 50 million of victims are injured (WHO). This rate is the highest in the countries with low and moderate level of incomes. Therefore road traumatism remains a serious issue in these countries [2]. In developed countries due to national data bases there is a possibility to find risk factors and elaborate strategies directed to the improvement of giving aid to victims. As a rule, these data bases contain information about hospitalized victims. Though, a great number of the injured people (about $60 \%$ ) die before their admission to hospital [4].

In addition to traditional causes of getting injuries (road accidents, falling down) in recent years traumas due to terrorist acts have become leading once. In spite of the fact that the number of victims due to terrorism is not so much considerable as because of road accidents, their rate has been constantly increasing since 1970-s. On a global basis approximately 130000 of attacks were committed by terrorists between 1970 and 2013 [5, 6]. Except Antarctica none of the continents avoided the facts of terrorism and deaths of victims because of it. Injuries resulting from terrorist acts are similar to those received due to military events $[7,8]$ and differ from those got during road accidents, etc. It should be noted that the number of victims is of a massive character. These "unique injuries" are connected with terrorism creating substantial difficulties for the existing systems to give emergency medical aid, both from the point of view of organization and provision of aid [9-11]. The factors complicating the work of emergency medical aid system and influencing on the quality of giving aid to the injured people are: time delay of pre-admission stage, specificity of the obtained injuries, an unpredictable course of associated traumas, considering the character of the applied damaging factor, and inadequately trained medical staff.

The studies conducted have shown that the main cause of preventive deaths among those being injured under usual conditions is hypovolemic shock - 33\% [12, 13]. Under conditions of battle injury including terrorist acts the amount of potentially preventive deaths is about $24,3 \%$ (4 596 victims); a cause of death among the injured people in $91 \%$ was bleeding $(67,3 \%$ bleeding from the trunk, 19,2\% - main bleeding, 13,5\% bleeding from the limbs) [14]. Therefore, bleeding is one of the main causes of preventive deaths. Medical aid in case of such injuries has been studied substantially [15-17]. Application of hemostatic tourniquets is proved to be an effective method to arrest bleeding. Though, the majority of 
articles deal with the issues of isolated injuries of the limbs. Publications dealing with the analysis of bleeding arrest by means of hemostatic tourniquets in victims with associated trauma are practically absent.

Certain scientific papers admit that reperfusion of ischemic limb after a hemostatic tourniquet is removed and blood circulation is restored provokes inflammation of the injured places (reperfusion damage of organs and tissues is possible 60 minutes after local ischemia) [19]. In their turn, produced mediators of inflammation and other toxic substances cause disorders of vital organs after penetration to the systemic circulation [20,21]. Considering the mentioned above examination of the effect of hemostatic tourniquet [28] application in case of a combined injury is important, especially under conditions of delayed pre-admission stage.

Materials and methods. Hyperproduction of oxygen active forms (OAF) is known to be one of the leading mechanisms of damage after ischemia/reperfusion. Activation of electron-transport chain in mitochondria resulting in uncontrolled electron production with one-electron reduction of oxygen molecule and formation superoxide anion-radical occurs due to oxygen supply to the tissues [22]. The source of OAF is neutrophils and macrophages activated after the contact with ischemic tissues [23, 29]. OAFs initiate peroxide oxidation of polyunsaturated fatty acids and in case of excessive amount they promote damage of the cellular membranes. These processes result in the formation of a number of lipid peroxide oxidation (LPO) products which include lipid hydroperoxides, diene conjugates, peroxide radicals, Malone aldehyde, and Schiff bases. Quantitative definition of Malone aldehyde is most often used to assess LPO intensity and early detection of metabolic disorders in the body $[24,30]$.

Contrary to free radical processes there is antioxidant system in the body directed to maintenance of homeostasis. The first line of protection against OAF consists of antioxidant enzymes superoxide dismutase (SOD) and catalse. They promote a successive chain of reactions to neutralize superoxide anion-radical, first to hydrogen peroxide under the effect of SOD and then to water and molecular oxygen under catalase effect. Under physiological conditions there is a certain balance between the intensity of lipid peroxidation processes and antioxidant protection [24].

A working hypothesis of the experimental study is an assumption that under conditions of safe application of a hemostatic tourniquet from the point of view of time of its application reperfusion of ischemic tissues results in excessive formation of OAF, activation of neutrophils and macrophages, hyperproduction of toxic metabolites, signal molecules of cytokine line and other mediators of inflammation, producing a systemic effect on the body 
with vital disorders of internal organs in case of a combined trauma of the abdominal cavity against the ground of hypovolemic shock.

Objective: to clarify the effect of two-hour application of a hemostatic tourniquet and limb reperfusion on the dynamics of antioxidant-prooxidant balance in the internal organs in the model of a combined trauma of the abdominal cavity against the ground of hypovolemic shock.

Methods of the study. To realize the stated task the experimental study was performed on 80 nonlinear male rats with the body weight of 190-220 g according to the rules of «European Convention for the Protection of Vertebrate Animals used for Experimental and Other Scientific Purposes» (Strasburg, 1984). All the animals were divided into the groups: the control and three experimental ones ( 8 animals in each group). A hemostatic tourniquet was applied on both legs of animals from the experimental groups for 120 minutes under thiopental-sodium narcosis $\left(04 \mathrm{mg} / \mathrm{kg}^{-1}\right)$. An elastic strip «SWAT-T» (USA) $10 \mathrm{~mm}$ wide was used as a tourniquet corresponding to the tourniquet applied on the human femur. The tourniquet was tightened according to the indicator of effective pressure marked on it. The animals of the experimental groups were taken out from the experiment under conditions of thiopental-sodium narcosis $\left(60 \mathrm{mg} / \mathrm{kg}^{-1}\right)$ by the method of total bloodletting from the heart 1,3 and 7 days after reperfusion. In the control group animals were subjected to narcosis using an equivalent dose of thiopental sodium and then taken out from the experiment 2 hours later.

Multitraumas (polytraumas) of the abdominal organs were modeled in the experimental groups in association with ischemic-reperfusion syndrome in the following way: after thiopental sodium narcosis animals received a dosage blow in the abdominal region by means of a special devise; blood loss was achieved by surgery and cutting femoral vessels in the volume from 20 to $22 \%$ of the circulating blood volume of an animal during 1 minute (acute blood loss); ischemic-reperfusion syndrome was simulated by application of hemostatic tourniquets on both lower limbs of animals for two hours. The experimental animals were divided into 3 subgroups: 1 - reperfusion syndrome of the limb without bleeding and abdominal injuries was modeled; 2 - severe abdominal injuries and massive blood loss were modeled; 3 - severe abdominal injuries, massive blood loss and reperfusion syndrome were modeled. The data obtained were compared with the control group.

The indicated parameters were determined at the Central Scientific Laboratory of I.Ya. Gorbachevskiy Ternopil State Medical University.

The liver, kidney, lungs and femoral muscles of the lower limbs were taken for the study. The content of Malondialdehyde (MDA) [25], SOD activity [26], and catalase [27] 
were determined in these organs. Probability of differences between the control and experimental groups was assessed using non-parametric Mann-Whitney criterion. Differences were considered to be true with null hypothesis probability less than $5 \%(\mathrm{p}<0,05)$.

Results. The Table 1 demonstrates that 24 hours after reperfusion MDA content increased considerably in the internal organs of the experimental animals of the experimental group 1 compared with the control: in the liver - 2,3 times as much, in the kidney - 2,0 times, lungs $-2,4$ times and muscles - maximum 7,0 times $(p<0,001)$. In the experimental group -2 a maximum value 24 hours later was found in the liver where this index was reliably higher than that of the control $(p<0,001) 5,5$ times as much, in other organs a reliable difference was found in comparison with the control group: in the kidneys - 3,5 times, lungs - 3,3 times and muscles $-2,3$ times $(p<0,001)$. In the experimental group -3 a maximum value in the muscles and liver was 10,2 times as much $(p<0,001)$, in other organs: lungs $-4,9$ times and kidneys $-4,7$ times.

Three days later in the experimental group - 1 in the liver, kidneys and lungs MDA content decreased compared with the indices after 24 hours, but they remain reliably larger $(p<0,001)$ in comparison with the indices of the control group 2,0, 1,9 and 1,8 times respectively. 3 days later the index increased and was higher than that of the control 7,9 times $(p<0,001)$. In the experimental group -2 three days later a tendency to increasing the index in animals was found. A maximum value was found in the liver 6,1 times as much in comparison with the control group $(p<0,001)$. In other examined organs: kidneys $-4,0$ times as much, in the lungs - 3,5 times and in the muscles - 2,9 times $(p<0,001)$. In the experimental group -3 on the third day a sudden reliable increase of the indices was determined concerning the control ones $(\mathrm{p}<0,001)$ as well as concerning the indices 24 hours later, the maximum values were found in the liver and muscles: 16,3 and 11,1 times respectively; in the kidneys $-7,3$ times and in the lungs $-7,1$ times.

7 days later in the experimental group - 1 the index increased concerning the indices 3 days later. They remained reliably higher $(p<0,001)$ concerning the control indices: in the liver - 2,3 time, kidneys - 2,6 times, in the lungs - 2,3 times and muscles - 12,2 times. Contrary to the experimental group - 1 in the experimental group - 2 a tendency to decreasing of the index was observed in all the tissues, but they remained reliably higher $(p<0,001)$ concerning the control indices: in the liver - 3,2 times, kidneys - 2,8 times, lungs - 2,6 times and muscles $-2,2$ times. In the experimental group - 3 seven days later a tendency to increasing the indices in all the examined organs was observed: in the liver - 18,5 times, in the kidneys $-8,6$ times, lungs $-7,2$ times and muscles $-12,2$ times $(p<0,001)$. 
Table 1 - changes of MDA content $\left(\mathrm{mcmol} \cdot \mathrm{kg}^{-1}\right)$ in the tissues of the experimental animals due to reperfusion effect $(\mathrm{M} \pm \mathrm{m})$

\begin{tabular}{|c|c|c|c|c|c|}
\hline \multirow{2}{*}{ Organ } & \multirow{2}{*}{$\begin{array}{l}\text { Control } \\
(\mathrm{n}=8)\end{array}$} & \multirow{2}{*}{$\begin{array}{l}\text { Experimental } \\
\text { groups (EG) }\end{array}$} & \multicolumn{3}{|c|}{ Reperfusion time } \\
\hline & & & 24 hours & 3 days & 7 days \\
\hline \multirow{3}{*}{ Liver } & \multirow{3}{*}{$0,62 \pm 0,02$} & EG-1 & $1,41 \pm 0,02^{* * *}$ & $1,25 \pm 0,10^{* * *}$ & $1,42 \pm 0,24^{* *}$ \\
\hline & & EG-2 & $3,41 \pm 0,19^{* * *}$ & $3,77 \pm 0,21^{* * *}$ & $1,96 \pm 0,21^{* * *}$ \\
\hline & & EG-3 & $6,3 \pm 0,12^{* * *}$ & $10,05 \pm 0,44^{* * *}$ & $11,5 \pm 0,49^{* * *}$ \\
\hline \multirow{3}{*}{ Kidney } & \multirow{3}{*}{$0,76 \pm 0,04$} & EG-1 & $1,52 \pm 0,08^{* * *}$ & $1,42 \pm 0,04^{* * *}$ & $1,96 \pm 0,08^{* * *}$ \\
\hline & & EG-2 & $2,65 \pm 0,24^{* * *}$ & $3,06 \pm 0,18^{* * *}$ & $2,16 \pm 0,25^{* * *}$ \\
\hline & & EG-3 & $3,54 \pm 0,17^{* * *}$ & $5,57 \pm 0,28^{* * *}$ & $6,57 \pm 0,29^{* * *}$ \\
\hline \multirow{3}{*}{ Lungs } & \multirow{3}{*}{$1,33 \pm 0,03$} & EG-1 & $3,13 \pm 0,13^{* * *}$ & $2,45 \pm 0,09^{* * *}$ & $3,07 \pm 0,19^{* *}$ \\
\hline & & EG-2 & $4,42 \pm 0,14^{* * *}$ & $4,61 \pm 0,18^{* * *}$ & $3,47 \pm 0,21^{* * *}$ \\
\hline & & EG-3 & $6,49 \pm 0,30^{* * *}$ & $9,39 \pm 0,35^{* * *}$ & $9,59 \pm 0,29^{* * *}$ \\
\hline \multirow{3}{*}{ Muscles } & \multirow{3}{*}{$1,43 \pm 0,06$} & EG-1 & $10,07 \pm 0,41^{* * * *}$ & $11,39 \pm 0,61^{* * *}$ & $11,44 \pm 0,65^{* * *}$ \\
\hline & & EG-2 & $3,31 \pm 0,1^{* * * *}$ & $4,14 \pm 0,23^{* * *}$ & $3,17 \pm 0,28^{* * *}$ \\
\hline & & EG-3 & $14,63 \pm 0,91^{* * *}$ & $15,85 \pm 0,93^{* * *}$ & $17,43 \pm 0,93^{* * *}$ \\
\hline
\end{tabular}

Note. Here and in Tables 2, 3: ${ }^{*}$ - probability of differences concerning the control group

$\left({ }^{*}-\mathrm{p}<0,05 ;{ }^{* *}-\mathrm{p}<0,01 ;{ }^{* * *}-\mathrm{p}<0,001\right)$.

The obtained results are indicative of the fact that after reperfusion the processes of lipid peroxidation are substantially activated in the experimental internal organs, which is caused by OAF effect and free radicals of fatty acids received from the ischemic limb and initiated LPO in the internal organs.

A conclusion can be drawn that the syndrome of the body systemic reaction to inflammation is associated with the effect of pro-inflammatory cytokines and other mediators of inflammation, considering that MDA content is loosely associated with the degree of inflammatory reaction [4]. Microcirculatory disorders with development of hypoxia are known to occur under their effect that can promote another "false" pathologic circle with LPO intensification.

The experiments showed that LPO processes intensification occurred against the ground of a considerable decrease compared with the control group SOD activity in the liver, kidneys, lungs and muscles (Table 2). In the experimental group - 1 a minimum value was found 24 hours later that was reliable with the indices of the control group: in the liver 53,3\% as much, in the kidneys $-47,4 \%$, lungs $-60 \%(\mathrm{p}<0,001)$, in muscles $-77,8 \%(\mathrm{p}<0,01)$. In the experimental group - 2, 24 hours later in the tissues the index decreased in the liver $41,6 \%$ as much, kidneys $-63,2 \%$, lungs $-60 \%$ and muscles $-55,6 \%(\mathrm{p}<0,001)$. In the experimental group -3 similar to the previous groups SOD index decreased in all the tissue: in the liver - 
$75 \%$, kidneys $-78,9 \%$, lungs $-75 \%$ and muscles $-88,9 \%(\mathrm{p}<0,001)$.

Table 2 - change of SOD index (specific units/mg) in the tissues of experimental animals due to reperfusion effect $(\mathrm{M} \pm \mathrm{m})$

\begin{tabular}{|c|c|c|c|c|c|}
\hline \multirow[t]{2}{*}{ Organ } & \multirow{2}{*}{$\begin{array}{c}\text { Control } \\
(n=8)\end{array}$} & \multirow{2}{*}{$\begin{array}{l}\text { Experimental } \\
\text { groups }\end{array}$} & \multicolumn{3}{|c|}{ Reperfusion time } \\
\hline & & & 24 hours & 3 days & 7 days \\
\hline \multirow{3}{*}{ Liver } & \multirow{3}{*}{$0,24 \pm 0,014$} & EG-1 & $0,112 \pm 0,004^{* * * *}$ & $0,14 \pm 0,038^{* *}$ & $0,16 \pm 0,04$ \\
\hline & & EG-2 & $0,14 \pm 0,01^{* * *}$ & $0,11 \pm 0,01^{* * * *}$ & $0,10 \pm 0,007^{* * *}$ \\
\hline & & EG-3 & $0,06 \pm 0,01^{* * * *}$ & $0,05 \pm 0,01^{* * *}$ & $0,04 \pm 0,01^{* * *}$ \\
\hline \multirow{3}{*}{ Kidneys } & \multirow{3}{*}{$0,19 \pm 0,01$} & EG-1 & $0,10 \pm 0,01^{* * *}$ & $0,12 \pm 0,01^{* * *}$ & $0,14 \pm 0,01^{* *}$ \\
\hline & & EG-2 & $0,07 \pm 0,006^{* * *}$ & $0,08 \pm 0,008^{* * *}$ & $0,12 \pm 0,01^{* * *}$ \\
\hline & & EG-3 & $0,04 \pm 0,005^{* * *}$ & $0,05 \pm 0,004^{* * *}$ & $0,07 \pm 0,005^{* * *}$ \\
\hline \multirow{3}{*}{ Lungs } & \multirow{3}{*}{$0,20 \pm 0,01$} & EG-1 & $0,10 \pm 0,003^{* * *}$ & $0,13 \pm 0,01^{* * * *}$ & $0,15 \pm 0,01^{* *}$ \\
\hline & & EG-2 & $0,08 \pm 0,002^{* * *}$ & $0,10 \pm 0,01^{*}$ & $0,11 \pm 0,01^{*}$ \\
\hline & & EG-3 & $0,05 \pm 0,005^{* *}$ & $0,06 \pm 0,01^{*}$ & $0,07 \pm 0,002^{*}$ \\
\hline \multirow{3}{*}{ Muscles } & \multirow{3}{*}{$0,27 \pm 0,008$} & EG-1 & $0,06 \pm 0,001^{* *}$ & $0,07 \pm 0,002^{* * *}$ & $0,11 \pm 0,009^{* *}$ \\
\hline & & EG-2 & $0,12 \pm 0,003^{* * *}$ & $0,14 \pm 0,004^{* * * *}$ & $0,15 \pm 0,01^{* * *}$ \\
\hline & & EG-3 & $0,03 \pm 0,001^{* * *}$ & $0,04 \pm 0,003^{* * *}$ & $0,04 \pm 0,001^{* * * *}$ \\
\hline
\end{tabular}

Three days later in the experimental group - 1 SOD index increased in all the tissues, but they were reliably lower concerning the control indices: in the liver 41,6\% ( $p<0,01)$, in the kidneys $36,8 \%$, in the lungs $35 \%$ and muscles $74 \%(\mathrm{p}<0,001)$. In the experimental group -2 SOD indices remained reliably lower compared with the control ones: in the liver 53,3\%, in the kidneys $57,8 \%$, in the lungs $50 \%$ and muscles $51,9 \%(\mathrm{p}<0,001)$. In the experimental group - 3 the indices were reliably lower than those of the control ones: in the liver $79,2 \%$, in the kidneys 73,7\% ( $<<0,001)$, in the lungs 70\% $(\mathrm{p}<0,05)$, and muscles $85,2 \%(\mathrm{p}<0,001)$.

In the experimental group - 1, seven days later a tendency to increasing of SOD index was found. Thus, in the liver tissues it was lower than that of the control 33,3\% as much, which was not statistically reliable ( $p>0,05$ ), in the kidneys $26,3 \%$, lungs $25 \%$ and muscles $59,3 \%(\mathrm{p}<0,01)$. In the experimental group -2 SOD index decreased and was reliably lower $(\mathrm{p}<0,001)$ from the of the control $58,3 \%$ as much. In other tissues it increased and was statistically less than that of the control: in the kidneys 36,8 \% (p<0,001), in the lungs 45,0\% $(\mathrm{p}<0,05)$, in the muscles $44,4 \%(\mathrm{p}<0,001)$. In the experimental group -3 SOD index 
continued to decrease in the liver tissue and it was lower than that of the control indices $83,3 \%$ as much $(\mathrm{p}<0,001)$, it increased in the kidneys compared with the indices three days later, but it was reliably lower than that of the control $63,2 \%$ as much $(p<0,001)$, a similar tendency was found in the lungs, and in the muscles the index did not change.

The obtained data are indicative of the fact that LPO activation in the liver, kidneys, lungs and muscles occurs against the ground of exhaustion of one of the main enzymes of the antioxidant protection - SOD, which is likely to be spent on neutralization of oxygen active forms, but it does not homeostatic balance. Reperfusion syndrome in combination with multiple trauma against the ground of hypovolemic shock is likely to deteriorate considerably the body functional state and result in deep systemic changes, which consequences may be development of multiple organ failure.

In its turn, catalase activity in the internal organs against the ground of reperfusion in comparison with the control group increased considerably (Table 3). In the experimental group - 1 the index 24 hours later increased considerably that of the control and increased to the $7^{\text {th }}$ day in the liver $-20,4$ times, kidneys $-6,9$ times, lungs 3,5 times $(p<0,001)$. Meanwhile in the muscles catalase index was maximal during the first day, then till the seventh day it was 18,8 times higher than that of the control $(p<0,001)$. In the experimental group -2 , catalase index in the tissues of the kidneys, lungs and muscles increased till the third day, and then it decreased inconsiderably. It was 9,8 times higher in the kidneys than that of the control, in the lungs $-5,9$ times and in the muscles $-6,9$ times $(p<0,001)$. In the liver catalase index increased during the whole time of observation and it was maximal 7 days later, it was higher than that of the control 25,6 times as much $(p<0,001)$. In the experimental group - 3 contrary to the previous groups maximal catalase value was found 24 hours later. But on the third and seventh days it decreased sharply, especially in the tissues of the liver and muscles - catalase level increased reliably that of the control 14,6 and 11,7 times respectively $(p<0,001)$. In the tissues of the kidneys and lungs a similar tendency was observed, but the dynamics of changes was not so sharp. Thus, 7 days later catalase index was higher than that of the control in the kidney 5,6 times as much and in the lungs 6,0 times $(\mathrm{p}<0,001)$.

The obtained data are indicative of the fact that increased catalase activity possesses a compensatory value and is associated with enzyme specificity. Although increased catalase activity does not compensate intensification of lipid peroxidation processes, which is evidenced by accumulation of MDA in the internal organs and tissues. A sharp decrease of catalase indices in the experimental group - 3 is worth of mentioning here. Since the third day 
of the observation it can be indicative of exhaustion of the compensatory system and development of deep systemic imbalance in the system antioxidant-prooxidant balance.

Table 3 - changes of catalase index $(\mathrm{mcmol} / \mathrm{kg})$ in the tissues of the experimental animals due to reperfusion effect $(\mathrm{M} \pm \mathrm{m})$

\begin{tabular}{|c|c|c|c|c|c|}
\hline \multirow{2}{*}{ Organ } & \multirow{2}{*}{$\begin{array}{c}\text { Control } \\
(\mathrm{n}=8)\end{array}$} & & \multicolumn{3}{|c|}{ Reperfusion time } \\
\hline & & & 24 hours & 3 days & 7 days \\
\hline \multirow{3}{*}{ Liver } & \multirow{3}{*}{$0,45 \pm 0,013$} & EG-1 & $7,83 \pm 0,15^{* * *}$ & $8,58 \pm 0,24^{* * * *}$ & $9,18 \pm 0,25^{* * *}$ \\
\hline & & EG-2 & $10,21 \pm 0,45^{* * *}$ & $11,16 \pm 0,14^{* * * *}$ & $11,5 \pm 0,4^{* * *}$ \\
\hline & & EG-3 & $15,48 \pm 0,77^{* * *}$ & $13,57 \pm 0,53^{* * *}$ & $6,55 \pm 0,51^{* * *}$ \\
\hline \multirow{3}{*}{ Kidneys } & \multirow{3}{*}{$1,35 \pm 0,087$} & EG-1 & $9,48 \pm 0,34^{* * *}$ & $10,03 \pm 0,21^{* * *}$ & $9,33 \pm 0,15^{* * * *}$ \\
\hline & & EG-2 & $14,11 \pm 0,59^{* * *}$ & $16,61 \pm 0,62^{* * * *}$ & $13,23 \pm 0,35^{* * *}$ \\
\hline & & EG-3 & $18,42 \pm 0,62^{* * *}$ & $12,57 \pm 0,63^{* * *}$ & $7,51 \pm 0,55^{* * *}$ \\
\hline \multirow{3}{*}{ Lungs } & \multirow{3}{*}{$1,80 \pm 0,11$} & EG-1 & $6,07 \pm 0,08^{* * *}$ & $6,39 \pm 0,17$ & $6,28 \pm 0,31^{* * * *}$ \\
\hline & & EG-2 & $9,57 \pm 0,35^{* * *}$ & $12,2 \pm 0,43^{* * *}$ & $10,7 \pm 0,45^{* * *}$ \\
\hline & & EG-3 & $11,19 \pm 0,24^{* * *}$ & $10,05 \pm 0,37^{* * *}$ & $10,88 \pm 0,46^{* * *}$ \\
\hline \multirow{3}{*}{ Muscles } & \multirow{3}{*}{$1,70 \pm 0,103$} & EG-1 & $46,9 \pm 0,92^{* * *}$ & $34,69 \pm 1,26^{* * *}$ & $32,03 \pm 1,42^{* * *}$ \\
\hline & & EG-2 & $10,47 \pm 0,41^{* * *}$ & $11,97 \pm 0,52^{* * * *}$ & $11,85 \pm 0,66^{* * *}$ \\
\hline & & EG-3 & $49,39 \pm 1,25^{* * *}$ & $31,48 \pm 0,65^{\text {**** }}$ & $19,94 \pm 0,66^{* * * *}$ \\
\hline
\end{tabular}

The data of the study supported our hypothesis and proved availability of signs of systemic changes due to application of a hemostatic tourniquet, availability of a potential action of reperfusion syndrome in case of combined trauma of the abdominal organs against the ground of hypovolemic shock. Further studies in the direction of finding methods to correct systemic changes caused by reperfusion syndrome are perspective [31].

Conclusion. 1. After application of a hemostatic tourniquet reperfusion syndrome is associated with a long activation of lipid peroxidation processes in the tissues of the liver, kidneys, lungs and muscles, which is manifested by statistically reliable increase of MDA content maximum 7 days after reperfusion.

2. Intensification of LPO processes occurs against the ground of exhaustion of SOD activity in the liver, kidneys, lungs and maximum in the muscles.

3. The studies performed enable to extend the knowledge concerning the mechanism of injury of the internal organs after tourniquet application on the limbs and its reperfusion with a long activation of lipid peroxidation processes in the basis. These results are indicative of a high probability of development of multiple organ failure syndrome. 


\section{Literatura:}

1. World Health Organization. Global burden of disease, 2004 update Geneva: WHO Press; 2008.

2. World Health Organization. Global status report on road safety 2013: supporting a decade of action Geneva: WHO Press; 2013

3. Mortality Patterns in Patients with Multiple Trauma: A Systematic Review of Autopsy Studies / R. Pfeifer, M. Teuben, H. Andruszkow [et al.] // Plos One. - 2016. - Vol. 11 (2). doi: 10.1371/journal.pone.0148844

4. Patterns of mortality and causes of death in polytrauma patients-has anything changed? / R. Pfeifer, I. S. Tarkin, B. Rocos, H. C. Pape // Injury. - 2009. - Vol. 40 (9). - P. 907-911. doi: 10.1016/j.injury.2009.05.006

5. National Consortium for the Study of Terrorism and Responses to Terrorism (START). Global Terrorism Database. University of Maryland [Data file] (2015).

6. Regens J. L. Regional Variation in Causes of Injuries among Terrorism Victims for Mass Casualty Events / J. L. Regens, A. Schultheiss, N. Mould // Front Public Health. - 2015. - Vol. 3. - P. 198.

7. Champion H. R. Injuries from explosions: physics, biophysics, pathology, and required research focus / H. R. Champion, J. B. Holcomb, L. A. Young // J Trauma. - 2009. Vol. 66 (5). - P. 1468-1477.

8. Wounding patterns for U.S. marines and sailors during operation Iraqi freedom, major combat phase / J. M. Zouris, G. J. Walker, J. Dye, M. Galarneau // Mil Med. - 2006. Vol. 171 (3). - P. 246-252.

9. Traumatic brain injury: an overview of pathobiology with emphasis on military populations / I. Cernak, L. J. Noble-Haeusslein // J Cereb Blood Flow Metab. - 2010. - Vol. 30. - P. 255-266. 10.1038/jcbfm.2009.203

10. Terror medicine as part of the medical school curriculum / L. A. Cole, K. Wagner, S. Scott [et al.] // Front Public Health. - 2014. - Vol. 2. - P. 138. 10.3389/fpubh.2014.00138

11. Terror attacks increase the risk of vascular injuries / E. Heldenberg, A. Givon, D. Simon [et al.] // Front Public Health. - 2014. - Vol. 2. - P. 47. 10.3389/fpubh.2014.00047

12. Evaluation of preventable trauma death in emergency department of Imam Reza hospital / C. Gholipour, B. S. Rad, S. S. Vahdati [et al.] // World J Emerg Med. - 2016. - Vol. 7 (2). - P. 135-137. 
13. Evaluation of autopsy reports in terms of preventability of trauma deaths / Y. E. Eyi, M. Toygar, K. Karbeyaz [et al.] // Ulus Travma Acil Cerrahi Derg. - 2015. - Vol. 21. P. 127-133.

14. Death on the battlefield (2001-2011): implications for the future of combat casualty care / B. J. Eastridge, R. L. Mabry, P. Seguin [et al.] // J Trauma Acute Care Surg. 2012. - Vol. 73 (6 Suppl 5). - P. S431-437.

15. Butler F. K. Jr. Tactical combat casualty care: transitioning battlefield lessons learned to other austere environments. Tactical Combat Casualty Care: Beginnings / F. K. Jr. Butler // Fuhm Wilderness \& Environmental Medicine. - 2017. - Vol. 28. - P. S12-S17.

16. Died of Wounds on the Battlefield: Causation and Implications for Improving Combat Casualty Care / B. J. Eastridge, M. Hardin, J. Cantrell [et al.] // J Trauma. - 2011. Vol. 71. - P. S4 -S8.

17. Bochicchio G. Treatment of bleeding in the urban battlefield / G. Bochicchio // Surgery. - 2007. - Vol. 142. - P. S78-S83.

18. Eliminating Preventable Death on the Battlefield / R. S. Kotwal, H. R. Montgomery, B. M. Kotwal [et al.] // Arch Surg. - 2011. - Vol. 146 (12). - P. 1350-1358.

19. Lee C. Tourniquet use in the civilian prehospital setting / C. Lee, K. M. Porter, T. J. Hodgetts // Emerg Med J. - 2007. - Vol. 24 (8). - P. 584-587.

20. Van der Spuy L. Complications of the arterial tourniquet / L. Van der Spuy // South Afr J Anaesth Analg. - 2012. - Vol. 18 (1). - P. 14-18.

21. Wright G. Whould civilian pre-hospital emergency care provision include tourniquets for the management of uncontrolled traumatic haemorrhage? / G. Wright, V. S. Mcdonald, V. G. Smith. // Australasian Journal of Paramedicine. - 2015. - Vol. 12 (4). - P. $1-5$.

22. Murphy E. Mechanisms underlying acute protection from cardiac ischemia-reperfusion injury / E. Murphy, C. Steenbergen // Physiol. Rev. - 2008. - Vol. 88 (2). - P. 581-609.

23. Leukocytes and the inflammatory response in ischemiareperfusion injury / I. Francischetti, J. B. Moreno, M. Scholz, W. B. Yoshida // Rev. Bras. Cir. Cardiovasc. - 2010. - Vol. 25 (4). - P. 575-584.

24. Нагорная Н. В. Оксидативный стресс: влияние на организм человека, методы оценки / Н. В. Нагорная, Н. А. Четверик // Здоров’я дитини. - 2010. - № 2. - С. 140-145.

25. Доклінічні дослідження лікарських засобів: метод. рек. ; за ред. О. В. Стефанова. - К. : Авіценна, 2001. - 528 с.

26. Чивари С. Роль супероксиддисмутазы в окислительных процессах клетки и 
метод определения ее в биологических материалах / С. Чивари, И. Чаба, И. Секей // Лабораторное дело. - 1985. - № 11. - С. 678-681.

27. Метод определения активности каталазы / М. А. Королюк, Л. И. Иванова, И. Г. Майорова, В. Е. Токарев // Лабораторное дело. - 1988. - № 1. - С. 16-19.

28. Волотовська Н. В. Зміни активності глутатіонової системи внутрішніх органів у перші години експериментального ішемічно-реперфузійного синдрому кінцівки, поєднаного з крововтратою та механічною травмою / Н. В. Волотовська, Т. Кліфф Нхоквара, І. В. Жулкевич // Здобутки клінічної і експериментальної медицини. 2019. - № 1. - C. 23-27.

29. Особливості глікому структурних компонентів міокарда щура за умов експериментальної ішемії міокарда / Б. О. Надрага, Х. І. Струс, А. М. Ященко [та ін.] // Світ медицини та біології. - 2019. - № 3 (69). - С. 197-203.

30. Pathogenetic Features of Lipid and Protein Peroxide Oxidation Due to Experimental Acute Necrotizing Pancreatitis / V. V. Maksymyuk, M. I. Sheremet, V. V. Tarabanchuk [et al.] // Archives of the Balkan Medical Union. - 2019. - Vol. 54, no. 2. - P. 235-244. DOI: https://doi.org/10.31688/ABMU.2019.54.2.03].

31. Застосування препарату Ентеросгель для профілактики оксидативного стресу при гострій крововтраті / В. Г. Ніколаєв, І. М. Кліщ, І. В. Жулкевич [та ін.] // Вісник наукових досліджень. - 2009. - № 1. - С. 72-74.

\section{References}

1. World Health Organization. Global burden of disease, 2004 update Geneva: WHO Press; 2008.

2. World Health Organization. Global status report on road safety 2013: supporting a decade of action Geneva: WHO Press; 2013.

3. Pfeifer, R., Teuben, M., Andruszkow, H., Barkatali, B.M., \& Pape, H.-C. (2016). Mortality Patterns in Patients with Multiple Trauma: A Systematic Review of Autopsy Studies. Plos One. - 2016. - Vol. 11 (2). doi: 10.1371/journal.pone.0148844

4. Pfeifer, R., Tarkin, I.S., Rocos, B., \& Pape, H.C. (2009). Patterns of mortality and causes of death in polytrauma patients-has anything changed? Injury, 40 (9), 907-911. doi: 10.1016/j.injury.2009.05.006

5. National Consortium for the Study of Terrorism and Responses to Terrorism (START). (2015). Global Terrorism Database. University of Maryland. 
6. Regens, J.L., Schultheiss, A., \& Mould, N. (2015). Regional Variation in Causes of Injuries among Terrorism Victims for Mass Casualty Events. Front Public Health., 3, 198.

7. Champion, H.R., Holcomb, J.B., \& Young, L.A. (2009). Injuries from explosions. J Trauma, 66 (5), 1468-1477.

8. Zouris, J.M., Walker, G.J., Dye, J., \& Galarneau, M. (2006). Wounding patterns for U.S. marines and sailors during operation Iraqi freedom, major combat phase. Mil Med, 171 (3), 246-252.

9. Cernak, I., \& Noble-Haeusslein, L.J. (2010). Traumatic brain injury: an overview of pathobiology with emphasis on military populations. J Cereb Blood Flow Metab, 30, 255266. DOI: $10.1038 / \mathrm{jcbfm} .2009 .203$.

10. Cole, L.A., Wagner, K., Scott, S., Connell, N.D., Cooper, A., Kennedy, C.A.,..., \& Lamba, S. (2014). Terror medicine as part of the medical school curriculum. Front Public Health, 2, 138. DOI: 10.3389/fpubh.2014.00138.

11. Heldenberg, E., Givon, A., Simon, D., Bass, A., Almogy, G., \& Peleg, K. (2014). Terror attacks increase the risk of vascular injuries. Front Public Health, 2, 47. DOI: $10.3389 /$ fpubh.2014.00047.

12. Gholipour, C., Rad, B.S., Vahdati, S.S., Ghaffarzad, A., \& Masoud, A. (2016). Evaluation of preventable trauma death in emergency department of Imam Reza hospital. World J Emerg Med. 7 (2), 135-137.

13. Eyi, Y.E., Toygar, M., Karbeyaz, K., Kaldırım, Ü., Tuncer, S.K., \& Durusu, M. (2015). Evaluation of autopsy reports in terms of preventability of trauma deaths. Ulus Travma Acil Cerrahi Derg, 21, 127-133.

14. Eastridge, B.J., Mabry, R.L., Seguin, P., Cantrell, J., Tops, T., Uribe, P., ..., \& Blackbourne, L.H. (2012). Death on the battlefield (2001-2011): implications for the future of combat casualty care. J Trauma Acute Care Surg., 73 (6 Suppl 5), S431-437.

15. Butler, F.K.Jr. (2017). Tactical combat casualty care: transitioning battlefield lessons learned to other austere environments. Tactical Combat Casualty Care: Beginnings. Fuhm Wilderness \& Environmental Medicine, 28, S12-S17.

16. Eastridge B.J., Hardin M., Cantrell, J., Oetjen-Gerdes, L., Zubko, T., Mallak, C., \& Blackbourne, L.H. (2011). Died of Wounds on the Battlefield: Causation and Implications for Improving Combat Casualty Care (J Trauma.;71: S4 -S8)

17. Bochicchio, G. (2007). Treatment of bleeding in the urban battlefield. Surgery, 142, S78-S83.

18. Kotwal, R.S., Montgomery, H.R., Kotwal, B.M., Champion, H.R., Butler, F.K.Jr, 
Mabry, R.L., ..., \& Holcomb, J.B. (2011). Eliminating Preventable Death on the Battlefield. Arch Surg., 146 (12), 1350-1358.

19. Lee, C., Porter, K.M., \& Hodgetts, T.J. (2007). Tourniquet use in the civilian prehospital setting. Emerg Med J., 24 (8), 584-587.

20. Van der Spuy, L. (2012). Complications of the arterial tourniquet. South Afr J Anaesth Analg, 18 (1), 14-18.

21. Wright, G., Mcdonald, V.S., \& Smith, V.G. (2015). Whould civilian pre-hospital emergency care provision include tourniquets for the management of uncontrolled traumatic haemorrhage? Australasian Journal of Paramedicine, 12 (4), 1-5.

22. Murphy, E., \& Steenbergen, C. (2008). Mechanisms underlying acute protection from cardiac ischemia-reperfusion injury. Physiol. Rev., 88 (2), 581-609.

23. Francischetti, I., Moreno, J.B., Scholz, M., \& Yoshida, W.B. (2010). Leukocytes and the inflammatory response in ischemiareperfusion injury. Rev. Bras. Cir. Cardiovasc, 25 (4), 575-584.

24. Nagornaya, N.V., \& CHetverik, N.A. (2010). Oksidativnyj stress: vliyanie na organizm cheloveka, metody ocenki [Oxidative stress: effect on the human body, assessment methods]. Zdorovia dytyny - Health of the child, 2, 140-145 [in Ukrainian].

25. Ste-fanov, O.V. (Ed.) (2001). Doklinichni doslidzhennia likarskih zasobiv : metod. rek. [Preclinical drug research: Guidelines]. Kyiv: Avicenna, p. 528 [in Ukrainian].

26. Chevari, S., Chaba, I., \& Sekeř, I. (1985). Rol superoksiddismutazy v okislitelnykh protsessakh kletki i metod opredeleniia ee v biologicheskikh materialakh [Role of superoxide dismutase in cellular oxidative processes and method of its determination in biological materials]. Laboratornoe delo - Laboratory matters, 11, 678-681 [in Russian].

27. Korolyuk, M.A., Ivanova, L.I., Mayorova, I.G., \& Tokarev, V.Ye. (1988). Metod opredeleniya aktivnosti katalazy [Method for determination of catalase activity]. Laboratornoe delo - Laboratory matters, 1, 16-19 [in Russian].

28. Volotovska, N.V., Nhokwara, T.C., \& Zhulkevych, I.V. (2019). Zminy aktyvnosti hlutationovoi systemy vnutrishnikh orhaniv u pershi hodyny eksperymentalnoho ishemichnoreperfuzinoho syndromu kintsivky, poiednanoho z krovovtratoiu ta mekhanichnoiu travmoiu [Changes in the glutathione system's activity of internal organs in the first hours of experimental limb ischemia-reperfusion syndrome, combined with blood loss and mechanical injury]. Zdobutky klinichnoi i eksperymentalnoi medytsyny - Achievements of Clinical and Experimental Medicine, 1, 23-27. DOI 10.11603/1811-2471.2019.v0.i1.10043

29. Nadraha, B.O., Strus, Kh.I., Yashchenko, A.M., Zhulkevych, I.V., \& Lutsyk, O.D. 
(2019). Osoblyvosti hlikomu strukturnykh komponentiv miokarda shchura za umov eksperymentalnoi ishemii miokarda [Features of glycom structural components of rat myocardium under experimental myocardial ischemia]. Svit medytsyny ta biolohii - World of Medicine and Biology, 3(69), 197-203 [in Ukrainian].

30. Maksymyuk, V.V., Sheremet, M.I., Tarabanchuk, V.V., Shidlovskyi, O.V., Brodovsky, S.P., Zhulkevych, I.V., ..., \& Holiar, O.I. (2019). Pathogenetic Features of Lipid and Protein Peroxide Oxidation Due to Experimental Acute Necrotizing Pancreatitis. Archives of the Balkan Medical Union, 54 (2), 235-244. DOI: https://doi.org/10.31688/ABMU.2019.54.2.03].

31. Nikolayev, V.H., Klishch, I.M., Zhulkevych, I.V., Oleshchuk, O.M., \& Nikolayeva. V.V. Zastosuvannia preparatu Enteroshel dlia profilaktyky oksydatyvnoho stresu pry hostrii krovovtrati [Application of Enterosgel preparation for the prevention of oxidative stress in acute blood loss]. Visnyk naukovykh doslidzhen - Bulletin of scientific researches, 1 , 72-74 [in Ukrainian]. 